\title{
Aceh Tsunami Orphan Reinforcement through Orphan Kafala Program Policy, NGO Collaboration (OIC Alliance) with the Aceh Government
}

\author{
Cut Zamharira ${ }^{1}$, Muqni Affan Abdullah ${ }^{2}$ \\ \{cut_zamharira@yahoo.com¹,muqni_affan@yahoo.com ${ }^{2}$ \} \\ Ar-Raniry Islamic State University Banda Aceh, Indonesia ${ }^{1}$ \\ Ar-Raniry Islamic State University Banda Aceh, Indonesia ${ }^{2}$
}

\begin{abstract}
This paper examines the activities and results of the Aceh Tsunami Orphan Kafala Program policy, carried out by the NGO Organizations of Islamic Cooperation (OIC) Alliance in collaboration with the Aceh Regional Government. In accordance with the agreement between the OIC and the Indonesian government through the Ministry of Foreign Affairs, the OIC Alliance has a mission to help orphans of the Aceh Tsunami victims in the form of scholarships in the fields of education, health and training. In its implementation, OIC has partnered with national humanitarian institutions; Baitulmal Muamalat (BMM), Rumah Zakat and PKPU. The results of this study indicate that: (1) the total number of orphans who benefited from this program from 2006 - 2016 were 20,000 children spread across 6 districts / cities in Aceh, (2) the details of the programs that were running were: (a) living assistance, (b) mentoring and guidance, (c) education, (d) health (e) training and rehabilitation. Among the results of the program is the return of children who drop out of school due to the inability to pay to go to school and a number of children who graduate from high school can continue their education at the university.
\end{abstract}

Keywords: Reinforcement, Aceh Tsunami Orphan, Policy, Orphan Kafala Program, OIC Alliance, Aceh Government.

\section{Introduction}

Shocks that occur on the earth's surface due to seismic waves, or known as earthquakes, are common in Indonesia. This fact is caused by islands in Indonesia which are $80 \%$ located in high risk seismic areas in the world [1]. Earthquakes can be triggered by volcanic eruptions (volcanic earthquakes), shifts in the earth's crust (earthquake tectonics), even human activities (nuclear explosions). Aceh Province is located in three active segments of Sumatra. This is why the Aceh province often happen earthquakes [2]. Under certain conditions, earthquakes can cause or have potential tsunamis, including: earthquakes cantered in the middle of the sea and depths of less than 100 kilometers, earthquakes with strengths greater than 7 on the Richter scale, and earthquakes with faults or faults falling [3].

Tsunamis also occur due to waves caused by sudden movements of the earth's crust. According to the National Science Foundation (scientific institution in the United States), the wave of the December 2004 tsunami was recorded as the worst natural disaster in modern history. An earthquake with a magnitude of 9.3 magnitude and a tsunami that hit the coastal 
regions of South and Southeast Asia on December 26, 2004, caused more than 30,000 children to lose their parents and place of residence. The majority of the victims' children came from Aceh, Indonesia [4].

To find out and see first-hand the level of damage and the impact caused by the disaster, Malaysian Prime Minister Abdullah Badawi who was also chairman of the 10th Summit of member countries of the Organization of the Islamic Cooperation (OIC) visited Aceh in early 2005. Then, he consulted with the President of the Republic of Indonesia Mr. Susilo Bambang Yudhoyono. As for the follow-up of the visit, Abdullah Badawi proposed that the OIC Alliance help the orphans of the tsunami victims by supporting them. Then the chairman of the 10th OIC Summit contacted Prince Abdullah bin Abdul Aziz, both of whom agreed to initiate a supporting program for children who lost their parents in the tsunami disaster. Through an emergency meeting of representatives of OIC countries, led by Prince Saud Al Faisal and attended by the Secretary General of the Organization of the Islamic Cooperation and President of the Islamic Development Bank (IDB). The meeting agreed on a new program called "OIC Alliance for Children Victims of Tsunami".

A committee or steering committee that coordinates the Alliance is formed, which consists of: (1). OIC's Secretariat General, (2). Islamic Development Bank (IDB), (3). Malaysia, as chairman of the OIC Summit, (4). Turkey, as chairman of the OIC Minister of Foreign Affairs, Saudi Arabia and Indonesia. Furthermore, the steering committee agreed to involve civil society organizations and media circles in member countries and place them as partners for the activities of the Alliance. The meeting with civil society organizations was held at the office of the General Secretariat of the OIC on 28 February 2005. All organizations agreed to work under the umbrella of the Alliance. On June 29, 2005 in Sana'a, Yemen, the Organization for Islamic Cooperation then decided to form the OIC Alliance for Tsunami Victims' Children with the signing of a bilateral agreement between the Government of Indonesia and the OIC. So, according to the agreement between the OIC and the Indonesian government, the OIC alliance began to open its operational office on May 1, 2006 in Banda Aceh.

This paper will examine what the Aceh tsunami orphan policy program has been done by the OIC Alliance and the results that have been obtained by the beneficiaries of the program. Data is obtained through several stages, namely interviews with Aceh OIC staff, program implementers and program beneficiaries (orphans and guardians), observations on orphan empowerment activities carried out by the OIC Alliance and documentation in the form of annual reports from this program.

\section{Research Method}

This research was conducted by descriptive qualitative method, meaning that it carries out careful recording of phenomena that are heard, seen and read, both through interviews, field notes, and official documents. This method is used to find out, describe the types of activities from the OIC orphan program policy and the benefits obtained by program recipients. Data sources were obtained through interviews and documentation. The researcher interviewed the program manager, OIC staff, program implementers and orphans' guardians of the program and the Aceh government (Education Office, Social Service, Health Office and Keistimewaan Bureau). 


\section{Results and Discussion}

\subsection{Kafalah}

According to language, kafalah means to bear. Kafalah means the guarantee given by the guarantor (kafil), to the party he is responsible for. As the word of Allah SWT: "And He (Allah) made Zakaria as the guarantor of Maryam" [5]. Thus the notion of kafalah is to divert one's guaranteed responsibilities by holding on to the responsibilities of others as guarantor [6]. The conditions for being a kafil are baligh, have sense, are healthy, have authority in using their assets and are willing with their dependents.

\subsection{Orphans}

The word of orphan comes from Arabic, meaning a person who is left behind by his father (something that is alone). Orphan means by itself, he means someone who is not yet an adult and has died his father, so he is called an orphan, no one is helping and extending help to him [7]. An orphan is a child who dies his father, before he reaches adulthood, whereas if he is able to take care of his survival and is able to take care of outside of his interests, then he is not an orphan [8]. Thus, what is meant by an orphan is when someone dies his father, but he is not yet high and has not been able to provide for and care for his own life.

Orphans are one of the social problems that require serious handling. In the concept of distributive policy, the government is responsible for the provision of goods and services for citizens, including orphans. Helplessness, displaced both from basic needs and education, requires government intervention.

\subsection{Aceh Tsunami Orphan Program}

The OIC Alliance's mission is to support orphans of the tsunami victims in Aceh province by providing them health, education, guidance, training and rehabilitation services. The program also carries out the recovery of orphans who lost their parents. This is all done in line with Islamic values and the customs of the local community. All services will be provided to orphans in their place of origin, while cooperating and coordinating with government institutions.

The program assistance that will be carried out will be pursued in line with the Government program as formulated in the agreement that has been signed. The OIC Alliance office began operations on May 1, 2006 and became a mediator to coordinate the orphan sponsorship program and become a node that brings together orphans with their sponsors. The OIC Alliance targets to support 25,000 orphans in all of Aceh Province by providing assistance for their basic needs which include living expenses, housing, food, clothing, health, education assistance and secondary needs such as skills training and supporting activities in the social sector and body to return them to their lives and regain their identity in the midst of their own society.

The three work units at the OIC Alliance in Banda Aceh are:

a. Database, tasked with (a) providing a clear definition of each eligibility requirement, (b) setting Standard Operating Procedures for registration, verification, and acceptance of orphans who fulfil the requirements, and (c) establishing Standard Operating Procedures for replacement orphans who have not fulfilled the requirements.

b. The Core Program, is responsible for (a) ensuring that all orphans who have fulfilled the conditions, receive transfers on time, (b) ensure that all orphans are assessed for their 
development and welfare, ensuring there is supervision over future planning/ideals and development.

c. Finance, is responsible for establishing (a) an orphan payment system, (b) payment system for school supplies and additional classes, (c) procedures for tutor payment systems, (d) payment systems for skills training, (e) payment systems for health fund reimbursement, (d) payment systems for donations to dead orphans, and (e) payment systems for donations to married orphans.

The entire work unit is in the field, coordinating and jointly with the program implementers (PIA; Project Implementation Agency). The requirements for beneficiaries are: orphans (fatherless), orphan (parentless) orphans (motherless) and their father in poor condition, aged 18 years and under him, victims of the tsunami, conflict, and his father died normally, still actively in education both in formal and non-formal schools, mother / guardian not remarrying, families with poor economic conditions, not receiving assistance from other organizations or NGOs, residing in the project area.

\subsection{Living Cost Assistance Program}

Orphan program provide regular monthly assistance of 24 USD for food and shelter costs, 2 USD for mentoring and mentoring fees, 2 USD for tuition fees and medical expenses and training / rehabilitation for 1 USD each. A grant of 24 USD is transferred directly to the account of the orphans every month, while the amount of 6 USD is managed by the implementing agency and will be provided according to the needs of each child. Following are the details of the allocation of aid funds:

Table 1. Allocation of aid funds

\begin{tabular}{|l|c|l|}
\hline \multicolumn{1}{|c|}{ Type of Assistance } & Amount & \multicolumn{1}{c|}{ Information } \\
\hline Eat and place to live & $\$ 24$ & $\begin{array}{l}\text { Sent directly to orphan accounts for their } \\
\text { living expenses }\end{array}$ \\
\hline Guidance / Orientation & $\$ 2$ & $\begin{array}{l}\text { Monitoring orphan development, } \\
\text { providing guidance and psychological } \\
\text { support for orphans and guardians }\end{array}$ \\
\hline Education & $\$ 2$ & $\begin{array}{l}\text { Providing learning assistance and } \\
\text { monitoring children's learning progress } \\
\text { in school / providing additional lessons / } \\
\text { giving school kits, school stationery and } \\
\text { books / scholarship programs }\end{array}$ \\
\hline Health & $\$ 1$ & $\begin{array}{l}\text { Routine medical check-ups, } \\
\text { reimbursement of medical expenses, } \\
\text { emergency care and hospital stays. } \\
\text { Provision of free mobile clinics and } \\
\text { awareness-raising about healthy living. } \\
\text { Checking of child health problems } \\
\text { related to malnutrition }\end{array}$ \\
\hline Rehabilitation and skill training & $\$ 1$ & $\begin{array}{l}\text { Empowering children by equipping them } \\
\text { with various skills. }\end{array}$ \\
\hline
\end{tabular}

3.5 Collaboration between Project Implementing Agencies (PIA) 
The OIC Alliance carried out a process of verifying the data of orphans in Aceh by visiting them in each village and coordinating with the village apparatus. Data that was successfully verified is submitted to the project implementing agency (PIA: Project Implementation Agency).

PIA is an institution that carries out an MoU with the OIC alliance to implement an orphan capacity strengthening program in the field of supervision, education, health and training. There are three institutions that are the executors of the OIC Alliance program, namely Baitul Mal Muamalat (BMM), Pos Keadilan Peduli Umat (PKPU) and Rumah Zakat (RZ). BMM became the executor of orphan programs in Pidie and North Aceh districts to handle 3,025 orphans. While PKPU handled a number of 1485 of orphans in Banda Aceh, Aceh Besar and Sabang. For the Banda Aceh and Aceh Besar regions there is also the Rumah Zakat as the program implementer, with 800 as orphans. Until 2016, the total number of beneficiaries of orphan strengthening programs was 5,310

In its implementation, the three institutions collaborate with each other and share information as their learning material. Moreover, there are several areas that are the same as their areas of responsibility, even with different orphans, so that the program does not overlap and can be implemented well. Every three months, the PIA attends meetings with the OIC Alliance and reports on each quarterly report, related to orphans that are the responsibility of each institution. This report is accountable to the OIC alliance and becomes an evaluation material.

\subsection{Government and Community Response}

The government highly appreciates the program carried out by the OIC and IDB, after the tsunami that struck Aceh. Where this program is felt to be very useful, not only the scope is large, but also the implementation period. The program is planned to be implemented for up to 15 years, from 2006 to 2021 . So that the government, be it the central government through the foreign ministry that implements the MoU with the OIC, as well as the local government through the Aceh and Keistimewaan Bureau, social services, health services and education offices. Where the government is greatly helped, because basically the orphans and the poor are part of the government's responsibility. Appreciation from the government is also reflected through cooperation with OIC. For example, this orphan program synergizes with the Aceh government in this case the health department conducting a medical check-up to orphan beneficiaries.

While the response from the community is also very good and positive, where they consider this program as one of the programs that really touches the needs of the community especially the orphans and their families. Orphans who have dropped out of school due to lack of funds have finally been able to go back to school and study again like other children with monthly scholarship assistance given directly to them, as well as access to health services and skills are also met through the kafala program, so that those who have been reluctant to go to a doctor or health centre because of the inability of transportation costs and other costs have finally been able to enjoy these facilities, also visited with free medical facilities from the government. So, it can be concluded that this program is very beneficial for orphans and their families who are part of the community itself. 


\section{Conclusion}

Orphanage program policies in order to strengthen tsunami orphanage capacity have been well implemented by the OIC Alliance in collaboration with the central government and the Aceh government, and partnered with several national humanitarian agencies, clearly visible with the results achieved through its main programs in helping children orphans both in the field of health education and training. The total number of orphan beneficiaries of this program from 2006 - 2016 was 20,000. These results are not only felt by orphans but also their families and surrounding communities and the Aceh government especially those who feel greatly helped by this noble program where orphans are part of their responsibilities as well.

The ultimate goal of this program is the independence that must be owned by orphans in both the economic and social fields in addition to of course increasing capacity in the intellectual and spiritual fields of religion, and this has been reflected in the current conditions of Acehnese orphans, especially those who have received assistance from this program. those who still get it or who have become alumni of this program and are currently continuing their studies at the university level and some of those who have worked and made money from the abilities and expertise they have.

\section{References}

[1] H. S. Naryanto, "Analisis Potensi Kegempaan dan Tsunami di Kawasan Pantai Barat Lampung Kaitannya dengan Mitigasi dan Penataan Kawasan," J. Sains dan Teknol. Indones., vol. 10, no. 2, 2012.

[2] M. Affan, M. Syukri, L. Wahyuna, and H. Sofyan, "Spatial statistic analysis of earthquakes in Aceh province year 1921-2014: cluster seismicity,” Aceh Int. J. Sci. Technol., vol. 5, no. 2, pp. 54-62, 2016.

[3] Badan Meteorologi Klimatologi dan Geofisika, "No Title," Badan Meteorologi, Klimatologi, dan Geofisika, 2019.

[4] Organization of the Islamic Cooperation, "No Title," Organization of the Islamic Cooperation, 2019.

[5] QS. Ali Imran. Al-qur'an.

[6] D. Djuwaini and S. Z. Qudsy, Pengantar Fiqh Muamalah. Pustaka Pelajar, 2008.

[7] M. Q. Shihab, Tafsir Al-Qur'an Al-Karim: tafsir atas surat-surat pendek berdasarkan urutan turunnya wahyu. Pustaka Hidayah, 1997.

[8] Zamarkhsyariy, "Tafsir al-Kasysyaf Juz 1,” Mesir: Musthafa al-Babiy al-Halaby. 